\title{
E-Government Project Design in Developing Countries
}

\author{
Diana Frost ${ }^{1} \otimes$ and Banita Lal $^{2}$ \\ ${ }^{1}$ Nottingham Business School, Nottingham Trent University, Nottingham, UK \\ diana.frost@ntu.ac.uk \\ ${ }^{2}$ Nottingham Business School, Nottingham Trent University, Nottingham, UK \\ banita.lal@ntu.ac.uk
}

\begin{abstract}
The purpose of this paper is to develop a conceptual framework as an integrated approach to Electronic Government project design and evaluation in developing countries. Innovations In information and Communication Technologies (ICT) have resulted in a radical transformation of business models, opening new channels of communication and offering cost-effective methods for business processes. Research in e-Government underscores the adoption of these technologies by Governments for the provision of more effective and efficient service delivery. Yet failures of e-Government projects in developing countries are well-documented and a review of the literature suggests that there remains, to an extent, disconnects between e-Government research and actual policy formulation processes or professional practices in developing countries. This paper asserts that for these smaller economies, e-Government project design and evaluation necessitates a more integrated approach which draws from research in the eGovernment and ICT4D domains; thus, encompassing a multiple stakeholder perspective including Government (as primary stakeholder) and citizens/businesses. Such an approach that encapsulates the unique characteristics of smaller economies offers a practical analytical tool in their design of eGovernment projects, highlighting core components for consideration and identifying where misalignment between stakeholder needs and systems objectives may occur.
\end{abstract}

Keywords: Electronic Government, e-Government, ICT for development, ICT4D, Information and Communication Technologies, Information Systems.

\section{Introduction}

The convergence of Information and Communication Technologies (ICTs) is widely considered as a key underlying attribute of advanced economic systems [1, 2, 3, 4] and thus promoted as a solution for overcoming some of the issues pertaining to under-development in emerging economies [5]. Accordingly, these countries attempt to leverage new and rapidly diffusing digital media to become effective participants in an increasingly competitive global environment [6]. However, in a continually evolving knowledge-based era, technology diffusion has been uneven, with many economies facing often insurmountable challenges to the effective exploitation of opportunities that digital technologies offer as a new source of wealth. Such obstacles may include an inadequate physical infrastructure, insufficient technological capabilities, and ineffective ICT policies $[1,7,8]$. These challenges are particularly endemic in the implementation and sustainability of e-Government initiatives in developing countries $[9,10,11,12]$ and contribute to high rates of failure post-project implementation [12]. Thus, development and long-term sustainability of e-Government projects in developing countries are often derailed not only by institutional procedures, policies and capabilities, but also by extraneous factors such as the technological capabilities of end-users and misalignment between project outcomes and stakeholder expectations [11, 12, $13,14,15]$.

Research suggests that, as in the design of any information system, successful outcomes of an e-Government project are dependent on continued assessment of the project during its entire life-cycle, from the initial analysis (pre-design) phase to any post-implementation activities $[16,17,18]$. Any such process should necessarily be rooted in "a stakeholder-centric process which makes explicit both the desired and the current outcomes, and which supports the managed alignment of these throughout the project life-cycle" [16, p. 177]. However, the validity of extending traditional models of information systems evaluation to the design processes of e-Government projects is brought into question [18] as assumptions concerning decision-making processes, project management structures, financial sources, design processes and policy/regulatory procedures may not be appropriate in the context of e-Government. Furthermore, the design of any eGovernment project may necessitate coordination among a broad range of stakeholders including disparate Government ministries and departments, organisations, businesses and citizens. By the same token, evaluation of misalignment in stakeholder expectations $[19,20]$ should consider wide variations in stakeholder interests depending on the type of implemented e-Government service, be it a Government-to-Government (G2G), Government-to-Citizen (G2C), Government-to-Businesses (G2B) or Government-to-Employee (G2E) service. Indeed, the evaluation of multiple stakeholder interests in e-Government initiatives invariably represents a significant challenge as "the goals of national 
government, local government, public service providers (both profit-driven and not-for-profit), voluntary and community organisations and individual members of the public are rarely congruent" [16, p. 175].

Thus, in exploring existing evaluative processes for e-Government projects, a cursory examination of past literature on e-Government research in developing countries highlighted a focus on the supply-side issues in project implementation such as inadequate policy/regulatory frameworks, ineffective political support and an inefficient physical infrastructure $[11,13,21,22,23,24]$. In the same vein, the ICT for Development (ICT4D) literature on technology adoption and diffusion in developing countries highlights the demand-side challenges such as lack of broadband connectivity, lack of access to adequate technologies and low levels of ICT literacy [25, 26, 27]. However, the literature yielded limited evidence of an integrated or consistent approach to evaluative design processes for e-Government projects that combines a multidimensional approach in the examination of supply-side issues, with added focus on multiple stakeholder perspectives in project design $[16,28]$. Such an integrated approach which overlaps defined boundaries in the ICT4D and e-Government literature is more feasible to an exploration of the perceived barriers to the success of e-Government projects [29, 30], though past research continues to identify "noticeable gaps between academic theories, commercially available methodologies and actual evaluation practice" [18, p. 252]. Thus, in contemplating the demand-side and supply-side factors for consideration in e-Government, two key questions emerge:

- What are the core underlying components for success in the design of an e-Government project? and - How are the inter-relationships among these identified components described?

Motivated by the desire to understand these inter-dependencies and their impact on the success of e-Government projects in developing countries, this led to the formulation of a conceptual framework that defines an integrated approach to design and evaluation of e-Government projects. The framework advances a multifaceted exploration of key issues from the perspective of multiple stakeholders including Government as primary stakeholder, and other intended beneficiaries such as citizens, organisations, and businesses. The framework subsequently evolved from an examination of demand-side and supply-side issues in e-Government project implementation from the ICT4D and e-Government literature. It is therefore anticipated that the results of this research will contribute to the continued e-Government dialogue on project design and assessment processes and further the debate in the ICT4D literature on technology adoption and diffusion within developing countries.

The remainder of the paper is organised as follows. Section 2 provides a brief description of the approach to the methodology in the development of the conceptual framework. Section 3 discusses the process in the development of the conceptual framework which includes a review of the literature on information systems evaluation processes, with a narrowed focus on approaches to e-Government assessment. The section also examines literature in the e-Government and ICT4D domains with the overall aim to highlight any overlapping areas of research and identify the key components in the design and evaluation of e-Government projects in developing countries. Section 4 describes the conceptual framework, based on a review of the literature from Section 3. The framework highlights the interdependencies and interrelationships among the identified components and proposed approaches to analysing misalignment among these components. Section 5 discusses proposed future research for testing, and enhancing, the conceptual framework and discusses any perceived research limitations.

\section{Research Methodology}

A structured-case approach is adopted in the development of the conceptual framework. Such an approach based on:

“...the use of a formal process model comprising three structural components: a conceptual framework, a pre-defined research cycle and a literature-based scrutiny of the research findings, to assist the researcher in theory building. The conceptual framework represents the researcher's aims, understanding and theoretical foundations and the research cycle guides data collection, analysis and interpretation; together, these structures make the research process visible, record its dynamics and document the process by which theory is induced from field data. The literature based scrutiny compares and contrasts the outcomes of the research process with a broad range of literature to support or challenge the theory built" [31, p. 236].

An interpretivist research paradigm rooted in qualitative data analyses offers a "process of describing, interpreting and seeking understanding and possibilities in order to reach a shared meaning" [32, p. S3]. The initial conceptual framework is therefore developed from a critical review of the literature which assists in identifying the key research themes. The structured-case approach then follows an iterative non-sequential cycle in the refinement of the model through: (a) planning of the research to be undertaken; (b) data collection; (c) data analysis; and (d) reflection on the outcomes [31].

The literature is therefore first examined to gain an understanding of the primary components in e-Government design. These components are used in the development of the conceptual framework. Future research findings of e-Government projects in developing countries, and a continued critical review of the literature, will contribute to successive iterations and refinement of the framework. "Therefore, the conceptual framework is a series of evolving models that are reviewed and refined over the life of the research project." [31, p. 235]. 


\section{Components in E-Government Design \& Evaluation}

The literature highlights the critical importance of the effective measurement and evaluation processes to determine the added value of implemented information systems [16, 17]. Evaluation in this context is defined as "the process of analyzing the functioning and/or usage of a system so that decisions can be made concerning the effectiveness of the system in satisfying its design objectives [33, p. 17 - 18]. Such evaluation "happens in many ways (e.g. formally and informally), uses diverse criteria (e.g. financial, technical, social), follows rigorous methodologies or 'gut feelings' [18, p. 1]. Central to effective evaluation processes is an early identification of any potential misalignment between stakeholder needs and the applied information technology which may ultimately lead to correspondence failure, defined in the information systems literature as the lack of correspondence between objectives and evaluation [34]. One potential result of such misalignment "is that IS evaluation practice tends to become separated from business needs and plans on the one hand, and from organizational realities that can influence IS implementation and subsequent effectiveness on the other” [33, p. 6]. Thus, in the information systems (IS) literature, different approaches to evaluation are proposed: Beynon-Davies [34] discusses the adoption of evaluation techniques at different stages of the life-cycle - Strategic evaluation that occurs predesign with the objective of determining the feasibility of the proposed system; Formative evaluation which involves a continuous assessment of the system against its objectives during the development phase; Summative evaluation during post-implementation to determine cost/benefits of the system; and Post-mortem evaluation conducted if a system is abandoned prior to implementation. However, such traditional information system evaluation models typically focus on business performance and financial measures of success post-project implementation, with the host organisation serving as the primary, or invariably, the sole stakeholder in project development. More recent models encompass stakeholder perspectives in evaluation, using techniques such as measurement of user satisfaction with the information system. These models, however, may not be appropriate within the e-Government realm where:

"there might be several decision makers or stakeholders involved, with different opinions and possibly conflicting objectives and definitions of the problematic nature of the situation; there may be difficulties in quantification of many important factors; transparency and accessibility of the model will be very important, thus often ruling out mathematical models; the [operation research] person's role will often be one of facilitator with a group of participants; and uncertainties will not simply be reduced to probabilities". [35, p. 368]

Thus, in proposing models for evaluation of e-Government projects, a soft systems approach has been suggested, where the focus is on organisational and social aspects that are typically not accommodated within traditional approaches to IS evaluation [36]. Other more recent e-Government evaluation models suggest a multi-dimensional approach to eliciting information about system usage which may be generated from user feedback or technical measures of system performance $[37,38]$. Thus, e-Government evaluation is broadly categorised into two groups: "The first group focuses on measuring e-government success in terms of the "readiness" of a country's infrastructure, technological capacity, and resources....The second group of e-government evaluation studies focuses on evaluating the project in terms of how successful information technology has been on the ground' [39, p. 329]. However, as highlighted in the e-Government literature, "there is still widespread and continuing disagreement as to the factors and metrics to include in any formal ICT evaluation approach" $[36$, p. 160] and, therefore, little consensus in the literature on precisely what those primary components in e-Government evaluation should be. This may in part be due to the differences in stakeholder interests and levels of capabilities required that is defined by the type of implemented e-Government project. Moreover, with recent advances in information and communication technologies, the application of ICT in developing countries tends to a discussion of how the technologies can more effectively contribute to socio-economic development specifically in the achievement of outlined sustainable development goals [41] in sectors such as education and healthcare. This adds a layer of complexity in the evaluation of e-Government projects where, traditionally, the majority of e-Government projects had "clearly identifiable socioeconomic costs and benefits, for example, gains in time or money to pay government bills, or to comply with taxes and other dues, or to obtain a registration certificate." [39, p. 330], projects such as health information systems are more human development focused [39]. In addressing these challenges to e-Government evaluation, some researchers suggest a capabilities approach [39] to assess how the project meets development criteria where evaluation indicators include the ability of a community to "access information, process and evaluate information technology, and use it in the community members' own lives” [39, p. 330]. This cursory review of the e-Government and ICT4D literature suggests that any approach to evaluation should not only focus on the interrelationships among core components in project design but also encompass multiple stakeholder perspectives. Thus, in reflecting upon the different e-Government evaluation approaches proposed in the literature two key questions emerge:

- What are the core underlying components for success in the design of an e-Government project? and

- How are the inter-relationships among these identified components described?

Table 1. Key themes from e-Government literature

The answer to these two questions are explored through a review of the e-Government and ICT4D literature, and thus contribute to the development of the conceptual framework. This paper asserts by exploring these inter-relationships 
through the conceptual framework at every stage of the life cycle, potential misalignments between the core components can be identified. In exploring the literature to identify the underlying components that are viewed as key to e-Government

\begin{tabular}{|l|l|}
\hline Key theme & Source \\
\hline $\begin{array}{l}\text { Information infrastructure: information } \\
\text { sharing; information networks }\end{array}$ & {$[42,43,44,45,46,47]$} \\
\hline $\begin{array}{l}\text { Policy and regulatory frameworks: ICT } \\
\text { policy, education policy, telecommunications } \\
\text { policy }\end{array}$ & {$[1,39,46,48]$} \\
\hline $\begin{array}{l}\text { Technological capabilities: Staffing and } \\
\text { skills; IT literacy }\end{array}$ & {$[34,42,49,50,51,52]$} \\
\hline $\begin{array}{l}\text { Physical capital: ICT infrastructure; } \\
\text { technologies }\end{array}$ & {$[34,42,45,48,53,54]$} \\
\hline $\begin{array}{l}\text { Human capital: skills, individual } \\
\text { capabilities }\end{array}$ & {$[43,54,55]$} \\
\hline $\begin{array}{l}\text { Social capital: social networks, relationships, } \\
\text { community networks }\end{array}$ & {$[47,53,56,57,58,59]$} \\
\hline
\end{tabular}

success, several key themes emerged. The following sections discuss the six identified themes emerging from eGovernment research (and tangentially the information systems literature) and the ICT4D literature on core components underlying e-Government project design and implementation. Table 1 summarises the key themes and sources from the literature.

\subsection{Information Infrastructure}

The important role of information and knowledge in determining the pace of technological advancement is highlighted throughout the e-Government literature [43]. These information networks facilitate capacity development among developing countries and also assist economies in their awareness of, and adaptation to, changes in the global environment; thus, playing a positive role in socio-economic development [44]. These networks underlie the information infrastructure, defined as "a set of interlocking institutions that together guide or constrain the behaviour of consumers, suppliers, public officials and citizens" [60, p. 19] and that which encompasses "the technologies, organizations and capabilities that facilitate production and use of ICTs" [61, p. 13]. Hence, the concept of an information infrastructure by definition, moves focus away from the underlying telecommunications infrastructure and information systems to also include the role of individuals in facilitating effective information and knowledge exchange networks. Moreover, the information infrastructure is viewed as a key contributor to socio-economic development and to improving governance in developing countries through a number of mechanisms including: greater access to government services; facilitating participation in governance processes; rapid dissemination of news to the population; enhancing transparency and accountability of government and minimising barriers to participation in economic markets [44].

Of note in the development literature is the concept of regional resource aggregation defined as a form of interdependent relations between states that share common experiences and interests for the purpose of working together to achieve commonly set goals $[51,58]$. An in-depth discussion of the topic is not presented at this stage of our research; however, it is worth noting emphasis on the importance of shared values or characteristics for developing effective information exchange networks, what [62] appropriately calls the 'preconditions of success' or 'factors that enhance the chances of success', and that these factors range from the economic [63] and cultural [64] to the political [62].

\subsection{Policy and Regulatory Frameworks}

The creation of an effective telecommunications policy and regulatory framework within developing countries is viewed as particularly crucial for promoting competition in markets that have traditionally been dominated by monopoly providers. "As legal frameworks and laws provide a range of civil and criminal penalties and enforcement procedures, they are particularly essential to advance the e-government development agenda of a country" [46, p. 1935]. As such, the policy and regulatory framework contributes to a reduction in the perceived risk of investment in regions such as Africa that have long been described as regions of high investment risk [65]. However, the telecommunications sector presents a particular challenge as it is a "moving target...it not only moves constantly ahead but it also shifts direction about every half century" [66, p. 19]. Thus, in responding to the dynamic ICT sector, an effective policy framework should focus not only on areas such as telecommunications policies and regulation, but also on improving technological capabilities through education, incentives for ICT usage, and other policies concerning access such as security and privacy policies [1]. Moreover, the underlying policy and regulatory framework, viewed as a key component in the success of an implemented e-Government project, should at a minimum: facilitate information-sharing across Government agencies [47], promote competition in the 
sector [67, 68], provide access to tools and education to enhance ICT literacy [69], improve access [70, 71] and support ICT integration in sector-specific areas such as healthcare $[72,73]$.

\subsection{Technological Capabilities}

Woods [74] asserts that the "Information Revolution is more than the technology itself...integrated digital technologies (informatics) introduces a single tool with which to address a broad range of human and institutional development functions...it calls for allocation of resources to realize the potential of the technology and concepts" (p. 11). Accordingly, within the e-Government and ICT4D literature, a country's level of "technological capability" is another component used to evaluate the ability of the country to promote and sustain technological advancement [57]. The concept of technological capability therefore encompasses a broad range of definitions such as that which determines a country's overall capacity to innovate using modern technologies or the capacity of the country to exploit the advantages of ICT and internet-based opportunities $[75,76]$. The ICT4D literature typically considers technological capability under broad headings such as "capacity development", "capacity building" or "capacity enhancement" thus emphasising the ability of actors such as individuals, groups, organizations, institutions and countries to perform specified functions, solve problems and set and achieve objectives, by acquiring the requisite skills and developing the capability to use those skills [77, 78]. Therefore, assessments of technological capabilities encompass the technological absorptive capacities of end-users, such that "individuals need to be aware of the e-Government solutions and/or applications available and be able to adopt and use them" [84, p. 23]. Nonetheless, many developing countries exhibit low levels of requisite technological capabilities and a perceived slow pace of technological innovation which may be attributed to many domestic factors including the cultural value systems, neglect of formal education, apathy towards research and development, slow socio-economic development, inadequate policies, lack of resources, improper allocation of resources, poor economic performance, lack of political will and a general disregard for innovation [51,52]. Therefore, for the technological benefits of e-Government projects to be realised, the literature emphasises the need for developing countries to build capacities for exploiting potential technological advantages by increasing their level of technological capabilities, viewed as a scarce resource in many developing countries $[61,76]$.

\subsection{Physical Capital}

Central to the development of a knowledge-based economy are the underlying technologies that are crucial "not only for the rapid dissemination of information and knowledge but also for the creation of a Web of relationships that transcend national borders and bureaucratic barriers" [45, p. 4]. We use the term physical capital in this context to encompass the information and communication technologies that are viewed as essential to the development of e-Government [54]. However in the context of e-Government in developing countries the choice of adopted technologies is critical as these technologies should provide the most effective solution taking financial considerations (cost of the technology), environmental considerations (for example the terrain) or other infrastructural considerations (for example access to electricity). The ICT4D literature therefore emphasises that the selection of appropriate technologies is apt in developing countries that may face access challenges to the fixed physical infrastructure and that more appropriate technologies such as wireless and mobile technologies serve as viable alternatives for expanding the fixed line network [25, 79].

\subsection{Human Capital}

Human capital, that encompasses the skills and knowledge possessed by an individual, plays a critical role in capacity development through its "availability as a collective resource and through specific, individual contributions" [55, p. 19]. Inferentially, this suggests an increased need for higher levels of human capital as an economy becomes more knowledgeintensive [74]. "Just as physical capital is created by changes in materials to form tools that facilitate production, human capital is created by changes in persons that bring about skills and capabilities that make them able to act in new ways" [80, p. S100]. The human capital factor, or specifically the accumulation of knowledge and skills of each individual which can be acquired through formal education, on-the-job learning and training [58,81,82], is highlighted in the ICT4D literature and viewed as a key contributor to collective technological progress within a society [43]. Moreover, human capital is viewed as one of the important determinants of e-Government development [54, 83] as "e-government services, to the extent that they use mainly text-based communication, assume a high level of literacy." [83, p. 637] and further asserts that though the physical infrastructure facilitates the supply of e-Government, it is the level of human capital that determines its demand [83].

\subsection{Social Capital}

More recent information systems literature places greater emphasis on a socio-technical approach to systems design and development that encompasses not only the technical factors, but also the human and social factors that may impact system 
design [54]. It is this social capital that is more apparent in developing countries [56], as it encapsulates traditional forms of knowledge transfer and is defined as "the ability of individuals within a group to form relationships of trust, cooperation and common purpose." [58, p. 103]. Though authors remain divided about the exact perception of social capital or social cohesion within a society, few dispute its integral role in building capacity [53]. Authors such as Fukuda-Parr and Hill [77], Rodrigo [75] and Fountain [85] assert that this social capital is the foundational element for capacity development within a country and argue that small economies in particular are at a distinct advantage in establishing strong informal social networks, whether based on religion, cultural values, political affiliation, or economic status. Lundvall [57] further emphasises that small economies are at a comparative advantage since they are better able to develop closeness in social relationships. This argument is corroborated by Fukuda Parr and Hill [77] who state that "non-industrial societies have few formal institutions but they do have highly developed skills and complex webs of social and cultural relationships" (p. 9) that they can tap into.

It would be remiss not to mention that a key theme underlying the ICT4D literature is a lack of consensus on exact measures of social capital (alternatively called social cohesion). Woolcock [86] explicates three types of social capital (1) 'bonding' social capital which refers to the relations between family members and close friends; (2) 'bridging' social capital which refers to the relationships forged between more distant acquaintances and colleagues such as in the diaspora; and (3) 'linking' social capital which emphasizes vertical linkages with external formal institutions - and attempts to highlight the necessity of each type in the development of human capital, and knowledge creation and transfer [80]. Yet, no single measure of social capital exists. Unlike other forms of capital that use financial measures, social capital is defined by the type and extent of relationships among individuals. Coleman [80] further emphasises the challenges in applying social capital measures - "If physical capital is wholly tangible, being embodied in observable material form, and human capital is less tangible, being embodied in the skills and knowledge acquired by an individual, social capital is less tangible yet, for it exists in the relations among persons" (p. S100). Thus, in a review of the development literature, authors including Grootaert [56], Field [59], Fukuyama [87], Knack and Keefer [88], Narayan and Pritchett [89], Putnam [90] suggest that social capital can be measured by factors such as levels of trust in government and in communities, membership of organizations or different social groups, types of networks, network density and the characteristics of groups to which people belong.

\subsection{Summary}

In answer to the question - What are the core underlying components for success in the design of an e-Government project? - a preliminary literature review highlighted that six primary themes dominate the literature on exploring the success factors for e-government in developing countries. The identified themes are: (a) Information Infrastructure; (b) Policy and Regulatory frameworks; (c) Technological capabilities; (d) Physical capital, (e) Human capital and (f) Social capital. We therefore view these as the six components in e-Government design. In the development literature, a combination of the latter three factors - human, social, and physical capital - are viewed as significant contributors to a country's level of economic growth [56]. These forms of capital contribute to the overall investment in e-Government project development, and are as critical to its success as the level of financial capital. Therefore in answering the second question - How are the inter-relationships among these identified components described? - an understanding of the roles of human, social, and physical capital in contributing or supporting the development of the other components (that is Information Infrastructure, Policy and Regulatory Framework, and Technological capabilities) is sought. The following section discusses these interdependencies that emerged from an exploration of the ICT4D and e-Government literature.

\section{Interdependencies among components}

A clear distinction is made in the ICT4D and e-Government literature on the crucial role of social and human aspects in the development of information networks, policy and regulatory frameworks, and technological capabilities [53, 54, 75, 77, 85]. Furthermore, the literature emphasises the underlying role of information and communication technologies (physical capital) in the development of these components [45, 91, 92]. The Information Infrastructure, Policy and Regulatory Framework, and Technological Capabilities are therefore viewed as the core components in e-Government; that is, the overall enablers, as their presence creates an enabling environment for e-Government project development. To summarise the discussion from the previous section:

- Information infrastructure - characterizes the underlying information systems and the impact of institutions, social networks, and policies on its development;

- Policy and Regulatory Frameworks - encompasses an understanding of the policies (including ICT, education, and other policies), legal framework, international standards and the policy implementation process, and

- Technological capabilities - describes the capacity of the society to exploit the advantages of information and communication technologies and/or Internet-based opportunities.

In a similar vein human capital, physical capital, and social capital are regarded as facilitators, or the building blocks for each component: 
- Physical capital - in the context of e-Government, physical capital refers to the underlying telecommunication networks or information and communication technologies for access;

- Human capital - this describes the capacities of an individual such as the level of education, and

- Social capital - this refers to the capacities developed through interactions within a community or society

However, what is evident from the literature is the uneven contribution of the different forms of capital - for example, the initial review of the literature asserts the crucial roles of social capital and human capital in the development of technological capabilities, and physical capital is viewed on the periphery; that is, it facilitates or enhances the roles of the other forms of capital. In the development of technological capabilities for e-Government, it is the physical capital (information and communication technologies) that make it easier to develop capacities through information and knowledge exchange. We discuss these dependencies in more detail in the following subsections, highlighting the main components in e-Government project design and distinguish between the forms of capital that are the building blocks to each component.

\subsection{Technological capabilities: Social Capital and Human Capital}

There is a shift in focus in the literature, moving human capital from the periphery to the centre of economic growth theory; thus, increasing attention on the methods by which individuals in a society can accumulate knowledge and develop the requisite skills to sustain growth [8]. One of the primary contributors to capacity development is the presence of social networks as these networks facilitate the relationships that make it easier for people to collaborate [57, 58]. Likewise, the important role of social capital, the degree to which individuals in a community have cooperated for collective problem solving, is also asserted by Fukuda-Parr [77]: "capacity development is a larger concept [than human resource development].... it refers not merely to the acquisition of skills, but also to the capability to use them... this in turn is not only about employment structures, but also about social capital." (p. 10). Thus, the pivotal role of social relations in acquiring information, building capacities and improving the quality of education in a society is underscored throughout the development literature $[56,80]$. Moreover, social capital is viewed as a direct contributor to the creation of human capital [80], where social relations may promote interest in, and access to, information. Hence, the level of technological capabilities is not only dependent on the abilities of human capital to exploit the advantages of ICT, but also on relevant information networks for capacity building. Social capital contributes to the development of technological capabilities by facilitating the creation of effective networks for information and knowledge exchange.

Thus, requisite levels of technological capabilities are crucially dependent on the skills embodied by the individual, that is, the human capital and by social capital, the collective capabilities of a society or community. Past research suggests that development of these capacities can be enhanced by the presence of information and communication technologies (physical capital) making it easier for individuals and societies to collaborate for information and knowledge exchange. We therefore propose that:

The level of technological capabilities in a society is dependent on the human capital that may be acquired through the creation of relevant social networks.

Figure 1 offers a visual representation of the inter-dependencies between the three factors, highlighting the underlying roles of human capital and social capital in the development of technological capabilities.

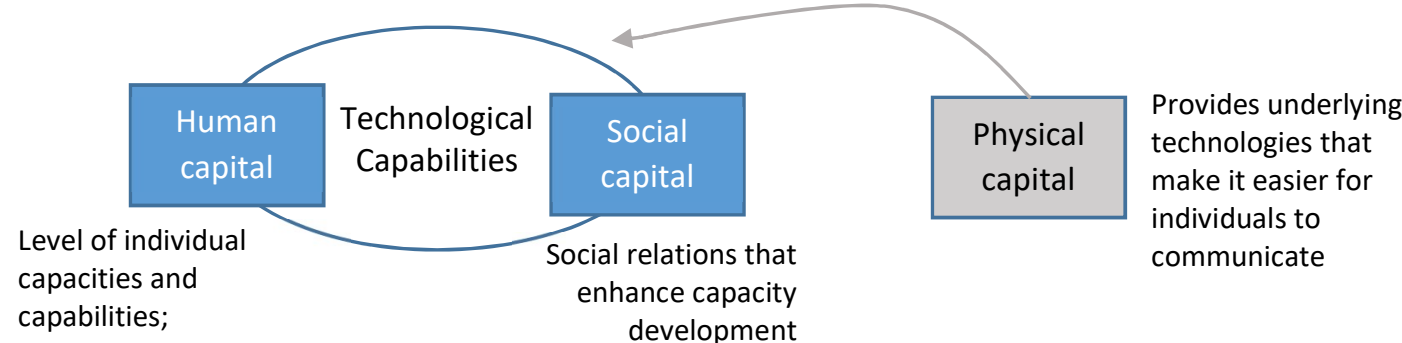

Fig. 1. Interdependencies - Technological capabilities (adapted from [96])

\subsection{Information infrastructure: Physical Capital, Social Capital}

The rapid innovations in information and communication technologies has underpinned the expansion of the knowledge economy, providing more convenient and ready access to information. Expansion and long-term sustainability of the information infrastructure is therefore dependent on the underlying physical infrastructure [91, 92], that is, the technologies utilized in the creation of the underlying information and communication networks [61].

"The development of the NII [National Information Infrastructure] in practice has encompassed technologies as diverse as POTS (Plain old telephone service), digital broadcasting, the Internet and other multimedia, in both the private and public sectors" [44, p. 54].

However, the information infrastructure is not defined solely by the technologies; the importance of social networks among individuals for facilitating knowledge exchange cannot be underestimated [59, 81, 93]. An examination of these 
networks in the context of e-Government therefore seeks to understand the role of community (and other support networks) in facilitating and enhancing information and knowledge exchange among individuals. As Bowles and Gintis [94] assert, that "communities can sometimes do what governments and markets fail to do because their members, but not outsiders, have crucial information about other members' behaviours, capacities, and needs" (p. F423). The underlying assumption is the pivotal role of community relationships in enhancing information and knowledge networks and thus, by extension, the role that such relationships play in supporting e-Government activities. Thus, we propose that:

The underlying physical infrastructure and the level of social capital influences the creation and sustainability of effective information networks to support e-Government.

Figure 2 offers a visual representation of the inter-dependencies highlighting the underlying roles of human capital and social capital in the information infrastructure and the supporting role of human capital.



Fig. 2. Interdependencies - Information Infrastructure (adapted from [96])

\subsection{Policy/Regulatory Framework: Human Capital, and Physical Capital}

The importance of an effective policy and regulatory framework is well-documented [1, 46]; however, the benefits of such a framework can be severely undermined if regulators lack the training, resources, or motivation to implement it [95]. Furthermore, developing countries may be slow in perceiving or reacting to events within the international system because of their lack of resources, especially of individuals who have the capabilities to navigate complex regulatory processes [95]. Thus, human capital plays a critical role in ensuring that effective policy and regulatory frameworks to support eGovernment are developed. What is evident is that the design of any policies is determined and shaped by the type of adopted technologies. Such policies may be general information and communications policies that facilitate access to and use of the information, or sector-specific such as policies in healthcare and education that may offer safeguards for security and privacy of data. Thus, we propose that:

The adoption of ICT is facilitated by the policy and regulatory framework, and the types of implemented policies are influenced by the available level of human capital for policy design and implementation.



Fig. 3. Interdependencies - Policy/Regulatory Frameworks (adapted from [96])

\subsection{Summary}

This section reviewed the literature to gain an understanding of the interdependencies and interrelationships among the core components in e-Government. The literature highlighted the primary components of technological capabilities, information infrastructure, and policy/regulatory frameworks. Development of each of the components are dependent on a combination of forms of capital, identified as: human capital, social capital and physical capital. A review of the eGovernment and ICT4D literature emphasised the crucial role of a combination of two forms of capital to the development of the components, with the third form of capital serving in a supporting role. The following section merges the results of this section in the development of the conceptual model.

\section{Conceptual framework}




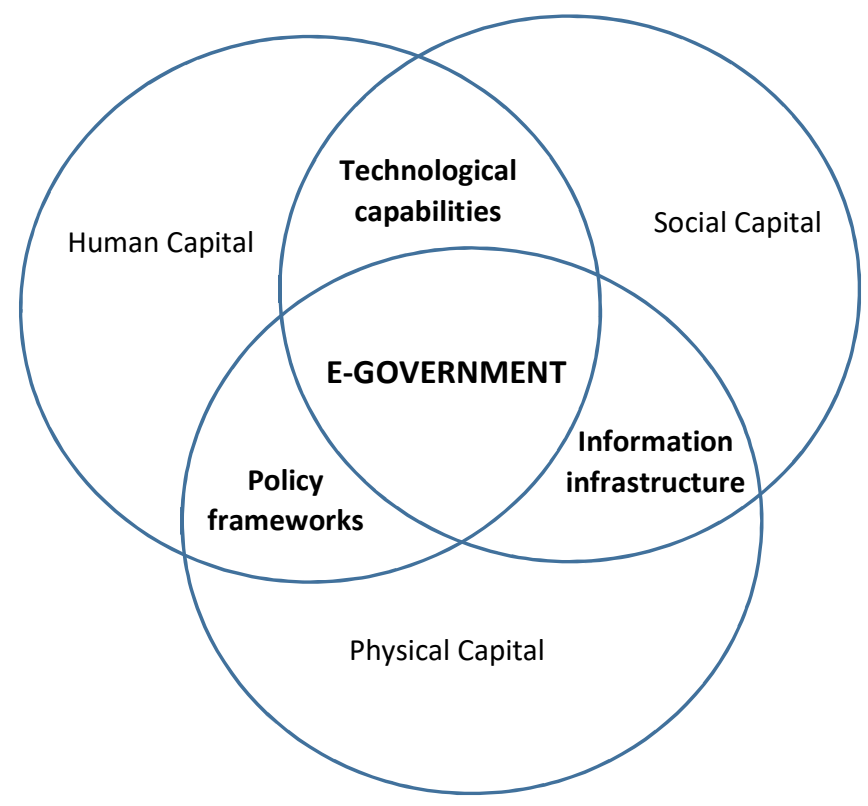

Fig. 4. Conceptual Framework for e-Government design (adapted from [96])

The review of the e-Government and ICT4D literature identified the core components that are influential in e-Government project design and highlighted the interdependencies among the factors that support the development of these core components. These relationships are shown in the developed conceptual framework that highlights the interdependencies and interrelationships among these components. Conceptually, the framework aims to draw focus upon those interrelationships among core defining components that are influential in project design and, thus, helps to identify where misalignment may occur that can ultimately lead to project failure. The conceptual framework, visualised in Figure 4, highlights the dynamic, multi-dimensional nature of research into e-Government project design and benefits from theoretical foundations in the ICT for Development and e-Government literature. To understand these interdependencies within a wider context, the authors intend to analyse this framework using data from an existing e-Government project in order to obtain conclusions leading to the development of the conceptual framework. Thus, initial research will focus on an in-depth case study that will lead to drawing relevant conclusions that can further refine the conceptual model and extend the research to an examination of the framework within the context of a developing country.

The conceptual framework underscores the multi-dimensional approach to e-Government design and evaluation, highlighting the core components - namely: technological capabilities, information infrastructure and policy frameworks - and the combination of supporting factors that are required for their development. Thus, technological capabilities lie at the intersection of human capital and social capital as, without the development of either, sustainability of adequate levels of technological capabilities is unlikely. Conversely, the framework helps to identify those components that are most influenced by changes in the underlying factors of physical capital, social capital and human capital. Therefore, any approach to e-Government requires a systemic approach in examination of these factors and address any imbalances in requisite levels for e-Government success as the framework brings focus to those areas where misalignment may occur; for example, where levels of human capital do not sufficiently satisfy the technological capabilities required for the eGovernment project or, conversely, where the project does not adequately help to achieve desired goals in increasing human capital. Moreover, any such analysis of these components should proceed in parallel as the components exhibit close interdependent relationships.

Therefore, in examining each component, several questions need to be addressed; thus, the following paragraphs briefly discuss some questions that may arise when examining its role in e-Government. By no means exhaustive, the questions highlight the interdependencies in the relationships between the respective components:

1. Information infrastructure:

What is the existing underlying physical infrastructure?

What information networks have been created to support information/knowledge exchange?

Has social capital played a role in the development of these networks?

What is the role of these networks in developing technological capabilities?

2. Policy/Regulatory framework

What policies have been developed to support the implemented project? (and tangentially, how have the implemented policies facilitated, or hindered, the sustainability of the project?)

What are the capacities for policy design?

Who are the key policy decision-makers? 
What is the policy design process?

Who are the primary stakeholders and what are their roles in the process?

How does the process affect or impact on the adoption of technologies?

3. Technological capabilities

What is the existing level of technological capabilities (including access to requisite technologies)?

What is the existing level of social capital?

How are capacities and stakeholder expectations determined prior to project design?

What initiatives have been promoted to support the development of capabilities?

What are the initial stakeholder requirements?

Do stakeholder expectations align to project outcomes?

The initial research will examine the design and implementation of a single e-Government project within a developed economy. Though there are inherent differences in institutional structures, culture, policy and regulatory frameworks, socio-economic characteristics and technology capabilities, examination of the central components within the context of a developed economy provides a constructive platform for further refinement of the conceptual framework. However this research will then be extended to developing countries, to focus on the inherent characteristics these countries leverage to take advantage of the opportunities offered by the introduced technologies.

\section{Implications, Limitations and Future Research Directions}

This paper developed a conceptual framework to examine the interdependencies among factors in the design and development of e-Government projects by exploring the e-Government and ICT4D literature. The complexities of this multidimensional approach to e-Government are apparent but, as this paper asserts, adopting such an approach helps in identifying any misalignment between stakeholder needs and the implemented technology. As Baxter and Sommerville [97] assert "the failure of large complex systems to meet their deadline, costs, and stakeholder expectations are not, by and large, failures of technology. Rather, these projects fail because they do not recognise the social and organisational complexity of the environment in which the systems are deployed" [p. 10]. Thus, complexities and questions in the design and evaluation of e-Government using this framework are evident. For example, complexities arise in deciding approaches to stakeholder identification. Qualitative techniques such as interviews (including focus group discussions) may be required to effectively collect data from stakeholder groups; however, once those stakeholder groups have been identified, how will users be selected to participate? Or, in examining the processes for policy design and implementation where multiple disparate Government ministries and departments are involved and/or require a protracted ratification through a central ministry, how can capacities for policy development be effectively determined? Further, as the literature showed, social capital poses a significant challenge as there is little consensus on structured approaches to its measurement. Moreover "if the dominant definition of social capital is in terms of networks and norms, the question of how to strengthen these is an open one" [98, p. 24]

In adopting the structured-case method approach, continued research in the area will include the collection, analysis and interpretation of data from research conducted on e-Government projects in developing countries to help further refine and redefine the framework. Application of the framework using qualitative and quantitative data gathered from the case studies will require an examination of each of the components and include further exploration of the literature for in-depth analyses of the existing theoretical models and approaches to measures for each of the components. As the framework is intended to examine these issues through the entire systems life cycle, and further to post-implementation activities, continued and future research will examine longitudinal studies of e-Government projects. To further refine the model, future research will be conducted using projects across multiple sectors and encompassing multiple stakeholder groups.

However, the application of the framework is not without its limitations. The framework omits extraneous factors that though discussed in the e-Government literature as influential in success or failure, are not only difficult to define or measure but also difficult to encapsulate within the formal framework. These factors include the pervasiveness of political corruption [24] or end-user trust and confidence in Government agencies [26]. In refining the framework, these extraneous factors may need to be included in future successive iterations. Grimsley et al [16], for example, emphasise that levels of social capital help to build end-user trust in e-Government and contrariwise. The conceptual framework, however, is a broad starting point to a discussion and exploration of these issues and we posit helps bring added focus to e-Government design and evaluation processes.

\section{REFERENCES}

1. Jorgenson, D. and Vu. K. 2016. "The ICT revolution, world economic growth, and policy issues". Telecommunications Policy, 40(5), pp. $383-397$. 
2. Vu, K. 2011. "ICT as a source of economic growth in the information age: Empirical evidence from the 1996 - 2005 period". Telecommunications policy, 35(4), pp. $357-372$.

3. Lee, S., Gholami, R. and Tong, T. 2005. "Time series analysis in the assessment of ICT impact at the aggregate level - lessons and implications for the new economy". Information \& Management, 42(7), pp. $1009-1022$.

4. OECD. 2003. ICT and Economic Growth: Evidence from OECD countries, industries and firms. Available at http://www.oecdilibrary.org/science-and-technology/ict-and-economic-growth_9789264101296-en, accessed on $3^{\text {rd }}$ March 2018.

5. World Bank. 2012. ICT for Greater Development Impact: World Bank Group Strategy for Information and Communication Technology, 2012 - 2015. Washington, DC: World Bank. Available at https://openknowledge.worldbank.org/handle/10986/27411, accessed on $3^{\text {rd }}$ March 2018.

6. Erumban, A.A. and Das, D.K. 2016. "Information and communication technology and economic growth in India". Telecommunications Policy, 40(5), pp. 412 - 431.

7. Vicente, M. and Gil-de-Bernabé, F. 2010. "Assessing the broadband gap: From the penetration divide to the quality divide". Technological Forecasting and Social Change, 77(5), pp. 816-822.

8. Morrison, A., Pietrobelli, C. and Rabellotti, R. 2008. "Global value chains and technological capabilities: A framework to study learning and innovation in developing countries". Oxford Development Studies, 36(1), pp. 39 - 58.

9. Das, A., Singh, H. and Joseph, D. 2017. "A longitudinal study of e-government maturity". Information and Management, 54(4), pp. $415-426$.

10. Ifinedo, P. 2011. "Factors influencing e-government maturity in transition economies and developing countries: A longitudinal perspective". Database for Advances in Information Systems, 42(4), pp. $98-116$.

11. Gil-García, J. and Pardo, T. 2005. "E-government success factors: Mapping practical tools to theoretical foundations". Government Information Quarterly, 22, pp. 187-216.

12. Heeks, R. 2002. "Information systems and developing countries: Failure, success and local improvisations". The Information Society, 18(2), pp. $101-112$.

13. Gunawong, P. and Gao, P. 2017. "Understanding e-government failure in the developing country context: a process-oriented study". Information Technology for Development, 23(1), pp. 153 - 178.

14. Kanda, S., Tuamsuk, K., and Chaopanon, W. 2015. "Factors affecting the development of e-government using a citizen-centric approach". Journal of Science and Technology Policy Management, 6(3), pp. 206 - 222.

15. Shareef, M, and Dwivedi, Y. 2011. "Electronic government adoption paradigms". In: Shareef, M, Kumar, V., Kumar, U., and Dwivedi, Y. (eds) Stakeholder adoption of E-Government Services: Driving and Resisting Factors. Hershey, PA: IGI Global.

16. Grimsley, M., Meehan, A. and Tan, A. 2007. "Evaluative design of e-government projects: A community development perspective". Transforming Government: People, Process and Policy, 1(2), pp. $174-193$.

17. Klecun, E. and Cornford, T. 2005. "A critical approach to evaluation". European Journal of Information Systems, 14, pp. 229 243.

18. Serafeimidis, V. and Smithson, S. 2003. "Information systems evaluation as an organizational institution - experience from a case study". Information Systems Journal, 13(2), pp. $251-274$.

19. Krishnan, S., Teo, T. and Lymm, J. 2017. "Determinants of electronic participation and electronic government maturity: Insights from cross-country data". International Journal of Information Management, 37, pp. $297-312$.

20. Heeks, R. 2003. "Most eGovernment-for-Development Projects Fail: How can risks be reduced? University of Manchester: Institute for Development Policy and Management". Available at: http://unpan1.un.org/intradoc/groups/public/documents/NISPAcee/UNPAN015488.pdf, accessed on 23 $3^{\text {rd }}$ February 2018

21. Pardo, T., Nam, T., and Burke, G. 2012. "E-Government interoperability: Interaction of policy, management, and technology dimensions". Social Science Computer Review, 30(1), pp. 7 - 23.

22. Shareef, M, Kumar, V., Kumar, U., and Dwivedi, Y. 2011. “e-Government Adoption Model (GAM): Differing service maturity levels". Government Information Quarterly, 28(1), pp. 17 - 35.

23. Cordella, A. and Iannacci, F. 2010. "Information systems in the public sector: The e-Government enactment framework". The Journal of Strategic Information Systems, 19(1), pp. $52-66$.

24. Aladwani, A. 2016. "Corruption as a source of e-Government projects failure in developing countries: A theoretical exposition". International Journal of Information Management, 36, pp. 105 - 112.

25. James, J. 2011. "Sharing mobile phones in developing countries: Implications for the digital divide". Technological Forecasting and Social Change, 78(4), pp. $729-735$.

26. Morgeson, F., VanAmburg, D. and Mithas, S. 2011. "Misplaced trust? Exploring the structure of the E-Government-Citizen trust relationship". Journal of Public Administration Research and Theory, 21, pp. $257-283$.

27. Mutula, S. 2008. "Digital divide and economic development: case study of sub-Saharan Africa". The Electronic Library, 26(4), pp. 468 - 489. doi: $10.1108 / 02640470810893738$

28. Rowley, J. 2011. “E-Government stakeholders - Who are they and what do they want?”. International Journal of Information Management, 31(1), pp. 53 - 62. doi: 10.1016/j.ijinfomgt.2010.05.005.

29. Helbig, N., Gil-García, J. and Ferro, E. 2009. "Understanding the complexity of electronic government: Implications from the digital divide literature". Government Information Quarterly, 26, pp. 89 - 97.

30. United Nations. 2016. "United Nations E-Government Survey: E-Government in support of sustainable development". Available at: https://publicadministration.un.org/egovkb/en-us/reports/un-e-government-survey-2016, last accessed on $3^{\text {rd }}$ March 2018.

31. Carroll, J.M. and Swatman, P.A. 2000. "Structured-case: a methodological framework for building theory in information systems research". European Journal of Information Systems, 9, p. 235 - 242.

32. Allan, J. 1998. "Perspectives on research in quality management", Total Quality Management, 9:4-5, 1-5, DOI: $10.1080 / 0954412988451$

33. Willcocks, L. 1994. Information management: the evaluation of information systems investment. London: Chapman \& Hall.

34. Beynon-Davies,P. 2009. Business Information Systems. Hampshire, England: Macmillan Publishers Limited.

35. Gupta, M.P. and Jana, D. 2003. "E-government evaluation: A framework and case study". Government Information Quarterly, 20 , pp. $365-387$. 
36. Irani, Z., Love, P.E.D., and Jones, S. 2008. "Learning lessons from evaluating eGovernment: Reflective case experiences that support transformational government". The Journal of Strategic Information Systems, 17(2), p. 155 - 164. doi: 10.1016/j.jsis.2007.12.005

37. Wood, F.B., Siegel, E.R., Lacroix, E.M., Lyon, B.J., Benson, D.A., Cid, V., and Fariss, S. 2003. “A practical approach to egovernment Web evaluation". IT Professional, Vol.5(3), pp. 22-28

38. Harris, R.W. 2015. "How ICT4D research fails the poor". Information Technology for Development, 22(1), pp. 177 - 192.

39. Madon, S., Sahay, S., and Sudan, R. 2007. "E-Government Policy and Health Information Systems Implementation in Andhra Pradesh, India: Need for Articulation of Linkages Between the Macro and the Micro". The Information Society, 23(5), p.327-344.

40. Baxter, G. and Sommerville, I. 2011. "Socio-technical systems: From design methods to systems engineering". Interacting with Computers, 23(1), p. $4-17$.

41. United Nations. 2015. "Transforming our world: the 2030 Agenda for Sustainable Development". Available at https://www.un.org/sustainabledevelopment/development-agenda.

42. Heeks, R. 2005. e-Government as a carrier of context. Journal of Public Policy, 25(1), pp. 51 - 74.

43. Borrus, M. and Stowsky, J. 1998. Technology Policy and Economic Growth. In Investing in Innovation: Creating a Research and Innovation Policy that works. L. M. Branscomb and J. Keller (eds.) Cambridge, MA: MIT Press.

44. Meso, P., Musa, P., Straub, D. and Mbarika, V. 2009. Information infrastructure, governance, and socio-economic development in developing countries. European Journal of Information Systems, 18, pp. 52 - 65.

45. Silvano, R. and Hanna, N. 2007. "New technologies for Public Sector Transofmration”. Journal of E-Government, $3(3)$, p. 3 - 39. DOI: $10.1300 / \mathrm{J} 399 \mathrm{v} 03 \mathrm{n} 0302$

46. Krishnan, S. and Teo, T. 2012. "Moderating effects of governance on information infrastructure and E-Government development". Journal of the American Society for Information Science and Technology. 63(10), p. 1929 - 1946.

47. Gil-García, J., Pardo, T. and Burke, G. 2015. “Conceptualizing information integration in Government”. In Schnoll, H. (ed.) EGovernment: Information, technology and transformation. Abingdon, Oxon: Taylor \& Francis Group.

48. Schware, R (Ed.). 2005. "E-development: From excitement to effectiveness". World Bank: Washington, DC. Available at http://documents.worldbank.org/curated/en/261151468325237852/pdf/341470EDevelopment.pdf.

49. Zakareya, E. and Zahir, I. 2005. "E-government adoption: architecture and barriers". Business Process Management Journal, $11(5)$, p. $589-611$

50. Cresswell, A., Pardo, T., and Canestraro, D. 2006. Digital capability assessment for eGovernment: A Multi-dimensional approach. In: Wimmer M.A., Scholl H.J., Grönlund Å., Andersen K.V. (eds) Electronic Government. EGOV 2006. Lecture Notes in Computer Science, vol 4084. Springer, Berlin, Heidelberg.

51. Kyambalesa, 2001. "The quest for technological development: Constraints, caveats and initiatives". University Press of America.

52. Madu, C. 1992. "Strategic planning in technology transfer to less developed countries". New York: Quorum Books.

53. Madon, S., Reinhard, N., Roode, D. and Walsham, G. 2009. "Digital inclusion projects in developing countries: Processes of institutionalization". Information Technology for Development, 15(2), pp. 95 - 107.

54. Siau, K. and Long, Y. 2009. "Factors affecting E-Government Development". The Journal of Compuiter Information Systems, 50(1), p. $98-107$.

55. Chaskin, R. 2001. Building community capacity: A definitional framework and case studies from a comprehensive community initiative. Urban Affairs Review, 36(3), pp. $291-323$.

56. Grootaert, G. (1998), "Social capital: the missing link", SCI Working Paper No. 3, World Bank, Washington, DC.

57. Lundvall, B. 2002. Innovation, Growth and Social Cohesion: The Danish Model. Cheltenham, UK: Edward Elgar.

58. Lall, S. 2002. "Social Capital and Industrial Transformation". In S.Fukuda-Parr et al.(eds.) Capacity Development: New Solutions to Old Problems. New York: UNDP, pp. 101 - 119.

59. Field, J. 2008. Social Capital. London: Routledge.

60. Wilson, E. 1997. The What, Why, Where, and How of National Information Initiatives. Downloaded from: http://www.ernestjwilson.com/uploads/The\%20What, $\% 20$ Why, $\% 20$ Where $\% 20$ and $\% 20$ How $\% 20$ of $\% 20$ National $\% 20$ Information $\%$ 20Initiatives.pdf

61. Mansell, R. and Wehn, U. 1998. Knowledge societies: information technology for sustainable development. Oxford, UK: Oxford University Press.

62. Kennes, W. 2000. Small developing countries and global markets - Competing in the big league. Basingstoke: Macmillan.

63. Venables, A. 2001. "Geography and international inequalities: The impact of new technologies". Journal of Industry, Competition and Trade, 1(2), pp. $135-159$.

64. Serbin, A. 1998. Sunset over the Islands: The Caribbean in an age of Global and Regional Challenges. Basingstoke: Palgrave MacMillan.

65. Collier P. and Pattillo C. (eds). 2000. Investment and Risk in Africa (Studies on the African economies). London: Palgrave Macmillan.

66. Perez, C. 2001. Technological change and opportunities for development as a moving target. In Toye, J. (ed.) Trade and Development: Directions for the $21^{\text {st }}$ Century. Cheltenham, UK: Edward Elgar.

67. Parker, D. and Kirkpatrick, C. 2007. Privatisation in developing countries: A review of the evidence and the policy lessons. The Journal of Development Studies, 41(4), p. $513-541$.

68. Buys, P., Dasgupta, S., Thomas, T., and Wheeler, D. 2009. "Determinants of a digital divide in sub-Saharan Africa: A spatial econometric analysis of cell phone coverage". World Development, 37(9), p. $1494-1505$.

69. Nishijima, M., Ivanauskas, T. and Sarti, F. 2017. "Evolution and determinants of digital divide in Brazil (2005 - 2013)". Telecommunications Policy, 41, pp. $12-24$.

70. Garbacz, C. and Thompson, H. 2007. Demand for telecommunication services in developing countries. Telecommunications Policy, 31(5), pp. $276-289$.

71. Ferro, E., Cantamessa, M. and Paolucci, E. 2005. Urban versus Regional Divide: Comparing and classifying digital divide. In Böhlen, M., Gamper, J., Polasek, W., and Wimmer, M. (eds.) E-Government: Towards Electronic Democracy, Proceedings of the International Conference, TCGOV 2005, Bologna, Italy. 
72. Haenssgen, M. and Ariana, P. 2017. "The social implications of technology diffusion: Uncovering the unintended consequences of people's health-related mobile phone use in rural India and China". World Development, 94, p. 286 - 304.

73. Khatun, F., Heywood, A., Ray, P., Hanifi, S., Bhuiya, A., and Liaw, S. "Determinants of readiness to support mHealth in a rural community of Bangladesh". International Journal of Medical Informatics, 84(10), pp. 847 - 856.

74. Woods, B. 1993. Communication, technology and the development of people. London: Routledge.

75. Rodrigo, G. 2001. Technology, Economic Growth and Crises in East Asia. Cheltenham: Edward Elgar.

76. Enos, J. 1991. The creation of technological capability in developing countries. Pinter Publishers.

77. Fukuda-Parr, S. and Hill, R. 2002. The network age: Creating new models of technical cooperation. In S.Fukuda-Parr, Lopes, C., and Malik, K. (eds.) Capacity Development: New Solutions to Old Problems. New York:UNDP.

78. Malik, K. Towards a normative framework: Technical cooperation, capacities and development. In S.Fukuda-Parr, Lopes, C., and Malik, K. (eds.) Capacity Development: New Solutions to Old Problems. New York:UNDP.

79. Gunasekaran, V. and Harmantzis, F. 2007. "Emerging wireless technologies for developing countries". Technology in Society, 29 , p. $23-42$.

80. Coleman, J. 1988. Social capital in the creation of human capital. The American Journal of Sociology, 94, p. 95 - 120.

81. Lever, W. 2002. "Correlating the knowledge-base of cities with economic growth". Urban Studies, 39(5-6), p. 859 - 870.

82. Jaffee, D. 1998. Levels of Socio-Economic Development Theory. Westport, CT: Praeger Publishers.

83. Singh, H., Das, A. and Joseph, D. 2004. "Country-level determinants of e-Government maturity". Available at https://pdfs.semanticscholar.org/7d1c/afd6c6010dc610898be6aa57036168b3b6f9.pdf.

84. World Bank. 2008. Global Economic Prospects: Technology diffusion in the developing world. Washington, DC: World Bank.

85. Fountain, J. 1998. "Social capital: Its relationship to innovation in science and technology". Science and Public Policy, 25(2), pp. $103-115$.

86. Woolcock, M. 2002. Social capital in theory and practice: Where do we stand? In Isham, J., Kelly, T., and Ramaswamy, S. (eds.) Social Capital and Economic Development: Well-being in Developing Countries. Cheltenham, UK: Edward Elgar.

87. Fukuyama, F. 1999. Social capital and civil society. Paper prepared for delivery at the IMF Conference on Second Generation Reforms. Washington, DC: International Monetary Fund.

88. Knack, S. and Keefer, P. 1997. Does social capital have an economic payoff? A cross-country investigation. The Quarterly Journal of Economics, 112(4), pp. 1251 - 1288.

89. Narayan, D. and Pritchett, L. 1999. "Cents and Sociability: Household income and social capital in rural Tanzania". Economic Development and Cultural Change, 47(4), pp. $871-897$.

90. Putnam, R. 1993. The prosperous community: Social capital and public life. Downloaded from http://prospect.org/article/prosperous-community-social-capital-and-public-life.

91. Ebrahim, Z. and Irani, Z. 2005. E-Government adoption: Architecture and barriers. Business Process Management Journal, 2005.

92. Talero, E. 1997. National information infrastructure in developing economies. In: Kahin B, Wilson E (eds) National information infrastructure initiatives: vision and policy design. MIT, Cambridge, pp 287-306.

93. Inkpen, A. and Tsang, E. 2005. "Social Capital, Networks, and Knowledge Transfer". The Academy of Management Review, 30(1), p. $146-165$.

94. Bowles, S. and Gintis, H. "Social capital and community governance". The Economic Journal, 112(483), p. F419 - F436.

95. Smith, P. and Wellenius, B. 1999. Mitigating Regulatory Risk in Telecommunications. Viewpoint. World Bank, Washington, DC. (C) World Bank. Downloaded from https://openknowledge.worldbank.org/handle/10986/11470.

96. Anius, D. 2005. Technology and Policy of a Regional Wireless Grid (unpublished doctoral thesis, Tufts University, 2004).

97. Baxter, G. and Sommerville, I. 2011. "Socio-technical systems: From design methods to systems engineering". Interacting with Computers, 23(1), p. 4 - 17. doi: 10.1016/j.intcom.2010.07.003.

98. Schuller, T. 2007. "Reflections on the use of social capital". Review of Social Economy, 65(1), p. 11 - 28. 